OPEN ACCESS

Edited by:

Mathias Fridahl,

Linköping University, Sweden

Reviewed by:

Shinichiro Asayama

National Institute for Environmental

Studies (NIES), Japan

Rikard Warlenius,

University of Gothenburg, Sweden

${ }^{*}$ Correspondence:

Stephen Hall

s.hall@leeds.ac.uk

Specialty section:

This article was submitted to

Negative Emission Technologies,

a section of the journal

Frontiers in Climate

Received: 12 May 2021

Accepted: 23 August 2021

Published: 21 September 2021

Citation:

Hall S and Davis M (2021) Permission to Say "Capitalism": Principles for

Critical Social Science Engagement With GGR Research.

Front. Clim. 3:708913.

doi: 10.3389/fclim.2021.708913

\section{Permission to Say "Capitalism": Principles for Critical Social Science Engagement With GGR Research}

\author{
Stephen Hall ${ }^{* *}$ and Mark Davis ${ }^{2}$ \\ ${ }^{1}$ School of Earth and Environment, University of Leeds, Leeds, United Kingdom, ${ }^{2}$ School of Sociology and Social Policy, \\ University of Leeds, Leeds, United Kingdom
}

The grand scale of GGR deployment now necessary to avoid dangerous climate change warrants the use of grand interpretive theories of how the global economy operates. We argue that critical social science should be able to name the global economy as "capitalism"; and instead of speaking about "transforming the global economy" as a necessary precondition for limiting climate change, instead speak about transforming, or even transcending, capitalism. We propose three principles are helpful for critical social science researchers willing to name and analyse the structural features of capitalism and their relation to greenhouse gas removal technology, policy, and governance. These principles are: (1) Greenhouse Gas Removal technologies are likely to emerge within capitalism, which is crisis prone, growth dependent, market expanding, We use a broad Marxist corpus to justify this principle. (2) There are different varieties of capitalism and this will affect the feasibility of different GGR policies and supports in different nations. We draw on varieties of capitalism and comparative political economy literature to justify this principle. (3) Capitalism is more than an economic system, it is ideologically and culturally maintained. Globally-significant issues such as fundamentalism, institutional mistrust, precarity, and populism, cannot be divorced from our thinking about globally significant deployment of greenhouse gas removal technologies. We use a broad Critical Theory body of work to explore the ideational project of maintaining capitalism and its relation to GGR governance and policy. Keywords: capitalism-varieties of, critical political economy, negative emission technologies, greenhouse gas
removal, critical theory

\section{INTRODUCTION}

In a recent analysis of limiting global mean temperature increase below $1.5^{\circ} \mathrm{C}$, Rogelj et al. (2018) find that all scenarios "achieving pronounced emission reductions require a transformation of the global economy." We agree that greenhouse gas emissions mitigation and emissions removals of the scale required to limit climate change to $1.5^{\circ} \mathrm{C}$ requires a "transformation of the global economy," but we also find a substantial lack of critical engagement from the humanities and social sciences (HASS) in what this "global economy" actually is, what assumptions we are making when we engage with more "instrumental" GGR research (Castree et al., 2014; Markusson et al., 2020), and how "we" as critical scholars can both maintain a healthy critical appraisal of the development of GGR in this global economy, while not disappearing from the debate because we question some of its founding 
premises. As Rose et al. (2012, p. 3) argue "The environmental humanities is necessarily [...] an effort to inhabit a difficult space of simultaneous critique and action." Perhaps the fastest route into this "difficult space" is to name and analyse the global economy as "Capitalism."

Approaching the global economy as "Capitalism" is a bold move. It detaches the discussion from a generalized term ("the global economy") and allows us to analyse a specific mode of production, as well as the cultural, social, and ecological relations that come along with it. In much of the world GGR will likely not emerge in feudalism, theocracy, socialism, or communism. Notwithstanding a revolution, it will emerge in capitalism. The "difficult space" we enter when we "say capitalism" is summarized by Žižek (2008). This difficult space exists because:

\begin{abstract}
"liberal-democratic capitalism is accepted as the finally-found formula of the best possible society; all one can do is to render it more just, tolerant, etc. The only true question today is: do we endorse this "naturalization" of capitalism, or does today's global capitalism contain strong enough antagonisms that will prevent its indefinite reproduction?" (Žižek, 2008, p. 37-38).
\end{abstract}

The tension is a real concern in calling for more critical engagement with GGR research, because this means there are two pathways for individual scholars. First, one accepts, or at the very least tolerates and works with, this naturalization of capitalism (see Jacobs and Mazzucato, 2016). One then goes on to apply a critical HASS lens to discrete elements of the problem at hand, such as securing public acceptance, securing state innovation resources, and/or rendering climate policies more just (Lamb et al., 2020). Here, social science has the primary role of mediating between policy, technology, and "the public" (Bellamy and Healey, 2018; Forster et al., 2020). New cultural and constructivist approaches are also emerging that explore the diverse publics and discourse surrounding GGR technologies, exposing the contested and multiple discourses, and framings of experts and/or publics and their perspectives on GGR technologies (Rose et al., 2012, Dowd et al., 2015; Lenzi et al., 2018; Waller et al., 2020).

Waller et al. (2020) identify three framings we can use to distinguish the different positions adopted by HASS researchers exploring the social and political dimensions of greenhouse gas removal: (1) a techno-economic framing; (2) a social and political acceptability framing; and (3) a responsible development framing. Both "techno-economic" and "social and political" framings are compatible with HASS researchers following the first path, naturalizing these studies within capitalism, albeit for many, with a specific aim of changing capitalism's course, rendering it more just or ecologically reproducible. Only in the "responsible development" framing do Waller et al., detect opportunities for challenging existing social orders, although Waller et al., leave these "social orders" undefined" ${ }^{1}$.

Cox et al. (2020a) explore a range of perceptions of risk and desirability of GGR technologies. They find that, for some, a barrier to acceptance of GGR technologies, is how they serve

\footnotetext{
${ }^{1}$ Let us be clear this is not an accusation of "omitting" capitalism, there is more than one term that can pass for a social order.
}

to perpetuate the current societal order, that is how GGR technologies justify a "non-transition" to a sustainable future society. In another contribution, Cox et al. (2020b, p. 211) reinterpret this dataset to infer that the "non-transitions" mean, in fact, a transition from "incumbent capitalist systems." For our analysis, we draw a line between those contributions that allude to some form of broader social order, and those that name capitalism as that social order.

To name capitalism in GGR research is to echo Žižek (2008) by not endorsing capitalism by omission, but to tackle what it means to grow the GGR "sector" within this specific mode of production. This second pathway, "saying capitalism" does not need to end in a rejection of capitalism in toto. It means exploring its structural contours, the social, and cultural features of capitalism that affect our study of the greenhouse gas removal field. It should lead us to take our own position on what role GGR plays in reproducing capitalism, and whether or not this is desirable. ŽiŽek has already drawn the conclusion that capitalism's relation to nature is one of four antagonisms strong enough to warrant a search for a new social order, a new means of production (Žižek, 2017). Humanities and social sciences researchers in GGR may or may not reach this conclusion, but to date there has been very little debate or scholarship to guide that journey despite some recent work beginning to make progress.

For example, Markusson et al. $(2017,2018)$ adopt an explicit cultural political economy analysis of carbon capture and storage (Markusson et al., 2017) and negative emission technologies (Markusson et al., 2018). In the CCS research (Markusson et al., 2017), they find that neoliberal political economies utilize CCS as a legitimating socio-temporal " $f i x$ " to the tensions between fossil capitalism and nature. CCS is found to be also a key discursive element in legitimating neoliberal political economics. In the Negative Emissions piece, Markusson et al. (2018) deploy the same analytical register, a "cultural political economy" to identify neoliberalism as a somewhat hegemonic cultural political economy, which is invisible to instrumental, managerial, realist social science. Similarly, whilst cultural and constructivist approaches invite us to explore more contested framings, they rarely name and analyse those framings within a dominant capitalist political economy.

In describing greenhouse gas removal technologies as a possible "spatio-temporal fix," Markusson et al. (2017, 2018) introduce a key term familiar to critical geographers but to date somewhat absent from the GGR debate. A "fix" is a way to maintain existing capital accumulation regimes using institutional and technological innovation, often by mobilizing state power (Jessop, 2006). Markusson et al. (2018) predominant concern, is the legitimization of mitigation deterrence at a policy level. They argue that moving to a cultural political economy register allows us to see and to critique how carbon capture and storage and greenhouse gas removal technologies can "fix" the problems climate change poses for capitalism by resolving the conflict between economic growth and emissions from hard to decarbonize sectors.

Within Markusson et al. $(2017,2018)$ contributions we see the beginning of a rich and productive debate. Within HASS scholarship and across the GGR community more broadly, 
however, we note a particular dearth of anchoring concepts or principles by which to conduct [cultural] political economy analysis. Why does capitalism need "fixing?" What are the structural features of capitalism which create the need for fixing and maintenance? Why do we persist with a system with such well-documented flaws? We intervene here to suggest some of these anchoring concepts and to explore what it means to see capitalism as in need of both material and ideational maintenance (Markusson et al.). In what follows, we explore where the need for "material" maintenance of capitalism, namely its interlinked tendencies toward crises, growth dependency, and market expansion.

\section{THE MATERIAL MAINTENANCE OF CONTEMPORARY CAPITALISM}

Materially maintaining capitalism means explicitly creating institutions, policies, regulations, or strategies to deal with the economic problems capitalism creates for itself. The three main problems we submit for analysis are intertwined and form Principle 1;

\begin{abstract}
"Greenhouse Gas Removal technologies are likely to emerge within capitalism, which is crisis prone, growth dependent, market expanding."
\end{abstract}

\section{CAPITALISM AS CRISIS PRONE}

Capitalism is crisis prone. Deep and "unpredictable" recessions occur where capital is not invested, unemployment mushrooms and productivity dramatically reduces. The need to "fix" capitalism, materially to maintain it, arises because capitalism is riven with contradictions and tensions that produce these crises (Harvey, 2017). The most obvious examples are the "Great Depression" of the 1930's and the recent 2008 Global Financial Crisis, though many more exist (Harvey, 2010). While it is clearly the case that economies often enter crises, dominant economic theory, namely the neo-classical school (Earle et al., 2016), at least until 2008 did not pay much attention to the systemic risk of crises. Instead, economists viewed the history of economic crises as a result of government intervention in otherwise perfect markets, or as generated by some exogenous interference in markets for capital, labor, and commodities that, if left to themselves, would stabilize over time (Bonizzi and Powell, 2020).

Beyond the neo-classical school, Marxist and Keynesian approaches instead argue that crises are inherent features of capitalism, with Keynesians arguing that periodic crises of capitalism are a result of mismatched periods of underconsumption (low effective demand) and under-investment (Bonizzi and Powell, 2020). Marxist analyses, notably Sweezy (1942), argue that crises are hardwired into the nature of capitalism, driven by its tendency to expand and speed up its capacity to produce consumer goods faster than the ability of consumers to purchase those goods. Both of these analyses center on the demand side or "consumption." Conversely, Marxist analysis also argues that crises can arise in the supply side of the economy, where the rate of profit reduces as competition in a sector intensifies. This eventually leads to an investment strike, as productive returns on further capital investment become difficult to find (Harvey, 2017). Marxist scholars also link the 2008 crisis to financial deregulation and easing of credit conditions, which was designed to allow wages to fall as output and associated consumption continued to increase. This indiscriminate extension of credit to cover consumer expenditures (particularly mortgages) was a "fix," which only postponed an inevitable crisis as wages stagnated while the productive capacity of economies continued to grow (Giacché, 2011; Shaikh, 2016).

Marxist analysis therefore sees crises as purgative, inevitable, even necessary events that resolve the pressure that builds up as a result of the contradictions inherent within capital accumulation. Indeed, it is these crises that make space for further rounds of productive investment (Harvey, 2014; also Schumpeter, 1934). The move to a Marxist or Keynesian approach, then, accepts crises as inherent to capitalism and, instead of blaming the state as the cause of crises, recommend either state intervention $a$ la Keynes, or following a Marxist tradition, explore how state intervention serves to regulate and reproduce capitalism (Jessop and Sum, 2006) often moving contradictions and crises around in time and space (Harvey, 2010).

The key insight for HASS scholars working on GGR is what this means for public policy and the role of the state at different levels. Humanities and social sciences scholars can build upon Marx and, particularly through Harvey $(2010,2014)$, analyse the state as a necessary manager of these crises. They may explore how this management drives the state to enable spatio-temporal "fixes" that manage, at least for some time, the crisis-tendencies inherent in accumulation (Jessop, 2006, p.146).

One such fix is a "switch" of capital from the circuits of production and consumption into other "circuits" of capital, such as large urban or infrastructural projects. Here, the stated objectives of urban projects are often secondary to the primary imperative of finding something for capital to invest in. Critical urban scholars have found the spatio-temporal fix argument extremely powerful in understanding the "real" drivers behind urban projects, uncovering the causal factors and power coalitions that emerge to secure such "fixes" and to explain why urban projects are successful if they achieve this objective, as opposed to any number of the local socio-economic improvements the projects promise to deliver (Apostolopoulou, 2021). Harvey's thesis is that urbanization or infrastructure investment is a particularly useful spatio-temporal fix, yet Markusson et al. and others (Carton, 2019) note climate policy and climate-facing investments can act as a "Socio-ecological fix" for the other contradictions of capitalism, namely relations to nature (also Ekers and Prudham, 2018).

There are two critical elements here that inform HASS GGR research. The first is that crises are not exogenous shocks that nobody can predict, but inherent features of capitalism that drive the state, as the regulating agent of capitalism, to enable spatiotemporal or socio-ecological fixes. Second, these climate policies are only legitimate in the eyes of state actors if they temporarily 
resolve crises. This resolution leads many to argue that this fix, be it material (i.e., the actual deployment of negative emissions) or discursive (i.e., the inclusion of negative emissions) in IPCC scenarios and models (see Carton, 2019) is temporal, in that it delays and dilutes the urgency of mitigation measures whilst at the same time legitimizing the continuation of fossil capitalism in the same way geo-engineering has served to do (Sapinski et al., 2020).

Seeing the state as key to the construction of both spatiotemporal and socio-ecological fixes is important because it gives us access to the real motivation behind so much climate policy. We can also use the notion of the socio-ecological fix and the spatial-temporal fix to question individual types of GGR deployment, to "see" proposals such as Zero Carbon Humber ${ }^{2}$ and the Northern Forest ${ }^{3}$ (to take two examples proximate to the authors) not as the result of an optimal decision for GGR deployment, but as attempts to re-produce capitalism in a given region.

Zero Carbon Humber is a consortium of industry partners in the economically disadvantaged Humber region in the UK. The region is home to multiple "difficult to decarbonize" industries which, in order to be compatible with a Net Zero economy, require carbon capture and storage to remain competitive in global markets. The consortium has mobilized state and private capital to construct CCS infrastructure which can be used by companies in the region to transport captured carbon dioxide from fossil fuelled processes into geological storage in the North Sea ${ }^{4}$.

If we view such proposals as a spatio-temporal fix or a socioecological fix we can then analyse them on this basis, how effective are they likely to be at achieving climate goals and protecting good industrial jobs in struggling regions? In the case of Zero Carbon Humber, maintaining both the labor and capital relations around port-based chemical and industrial production. What alternatives do they occlude if tackling climate change were the goal instead of safeguarding existing power relations and regimes?

By understanding crises as inherent to capitalism, and seeing state action as often a fix to such crises, GGR scholars can better appreciate that the most palatable projects and policies are going to be those that can postpone or displace these crises. Analyzed on this basis, "optimal" GGR deployment may look very different to scenarios based upon top-down techno-economic models.

\section{CAPITALISM AS MARKET EXPANDING}

In "The Origin of Capitalism," Wood (2002) explores how markets existed long before capitalism became the dominant mode of production and how the distinct feature of capitalism is how deeply it depends on markets, how the means of production, labor, and commodities are all offered for exchange in a market, instead of only the final commodity, with labor, machinery, land, etc., held by a feudal lord, a theocratic institution etc. (Polanyi

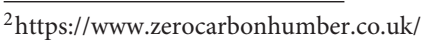

${ }^{3}$ https://thenorthernforest.org.uk/

${ }^{4}$ https://www.zerocarbonhumber.co.uk/the-vision
}

and MacIver, 1944). Markets, particularly for money and finance, are critical because they allow capital to change forms and to be invested elsewhere when the market for a given commodity becomes unprofitable (Harvey, 1978).

One source of crises is an inability to sell that which is produced, a crisis of realization where a market is saturated, obsolete, or there is no more effective demand. This is an interesting point for the capitalist who sells, for example lipstick. Because the cosmetics capitalist has reached a point where investing in more lipstick production is futile, they have a choice of where to invest next. If all other consumer goods markets are saturated they are not out of options. They can "switch" their capital into another circuit of production, those for example producing public goods such as infrastructure (Torrance, 2009). Again this is an example of a spatio-temporal fix, where capital that once produced cosmetics is now invested in bridges to avoid devaluation and perhaps structural crisis. There is a feat of financial engineering that is needed, however, to switch between circuits of capital. Castree and Christophers (2015) refer to this feat, stating how capital is made liquid by finance, how finance capital "melts present solidities into air to create different futures."

In order to achieve this switch there needs to be a form of "market making" that results in a reasonable expectation of profit. There must be the application of capital and a direct or indirect means of revenue capture to realize that profit. This has led to a burgeoning literature on the financialization of urban infrastructures (O'Neill, 2019), wherein the construction and protection of these revenue mechanisms by state and non-state actors is often prioritized in project planning to the exclusion of social, ecological, or even local economic benefit. Similarly, financialization and market making is needed for carbon trading, where a "market mechanism" is constructed to value and to trade carbon credits, artificial commodities constructed from the absence of emissions (Knox-Hayes, 2013).

For some time, the construction and promotion of market mechanisms to solve environmental problems have been legitimized through a broad Environmental Economics corpus that seeks to value and price nature and to construct markets for their protection (Groom and Talevi, 2020). This pricing and trading of nature to produce a "greener capitalism" (Böhm et al., 2012) gives rise to an intellectual divide between those who seek to internalize externalities with a price and market mechanism (see for a landmark example, The Stern Review, Stern, 2006), and those for whom ongoing trends of ecological commodification and expropriation, drive familiar processes of uneven and crisisprone development (Böhm et al., 2012), or worse are empiricallyblind to the non-substitutability of nature and unable to contend with hard "planetary boundaries" (Barbier and Burgess, 2017).

If we recognize that capitalism must expand the terrain for market exchange to avoid crises, then we should also be able to recognize that much of the debate over whether or not pricing nature is economically optimal is a moot point. It has to be legitimized because the space of market provision needs to expand to avoid crises. Developing social science around the marketization of previously non-market relations under capitalism is not a new phenomenon (Polanyi and MacIver, 
1944). For critical GGR scholars, we need to see the process of policy formation as an implicit search for market expansion, not an informed process of economic research that simply happens to diagnose competition and markets as the solution all the time (Bowman et al., 2014). A GGR policy is likely to be legitimate and desirable in the eyes of a capitalist state, only if it is easily linked to finance capital and a stable market mechanism can be found. We can recognize the market making tendency of capitalism in isolation, or we can see it as part of a wider "growth dependency" that forms the final pillar of Principle 1.

\section{CAPITALISM AS GROWTH DEPENDENT}

Economic growth in capitalism is inevitable, since this economic system is oriented towards unlimited and short term valorisation, quantitative and geographic expansion, circularity and reversibility (Büchs and Koch, 2017, p.9).

There is a wealth of debate about where growth comes from in an economy, which is beyond the scope of this paper to unpack. The neo-classical school focuses analysis upon expanding productive capacity from technological innovation. Marxian analysis argues that ever more capital has to be invested into the productive process due to the forces of competition. Keynesian analysis explores the role of aggregate demand (how much is spent on consumption). And, evolutionary economics details the role of entrepreneurs and "creative destruction" that makes way for new rounds of accumulation or growth (Bourayou and Van Waeyenberge, 2020).

The question of how growth happens is important to HASS scholars because where a HASS scholar lands in that debate will inform what types of economic stimulus are seen as legitimate. Yet there are still deeper and more critical questions about economic growth that need to be asked: Why is growth necessary in capitalism? Is growth necessary for human wellbeing? Is growth necessary for negative emission technologies?

To summarize "why" growth instead of "how" growth, we return to Harvey's (2014) Marxian analysis. Harvey explores how capital will only be invested if "it" (capitalists) believes there will be more money available at the end of an investment cycle than at the beginning. If there was no such belief investment of new capital in new rounds of production would cease, again causing crises, and a search for a "fix," such as a return to aggregate growth (Jackson, 2009). For this belief to exist, somewhere around a $3 \%$ compound growth rate is commonly regarded as "healthy" (Harvey, 2017). This means that new productive investments must be found for an exponentially-increasing volume of capital.

In our current climate science it is unthinkable that a period of no growth or "de" -growth can exist under capitalism. Even in the "transformation of the global economy" envisioned by Rogelj et al. (2018) an average GDP growth of $231 \%$ is envisaged across the global economy between 2020 and 2050 within pathways "consistent" with meeting the $1.5^{\circ}$ target (IIASA, 2020). IPCC growth scenarios notwithstanding, there remain serious questions over the assumed ability truly to decouple GDP and GHG emissions (Hickel and Kallis, 2020; Wiedenhofer et al., 2020).
There is now a substantial scholarship questioning whether "more growth is good" and whether a growing economy is healthy (Jackson, 2009, 2021; Raworth, 2017). This debate explores what structural changes are needed to bring a "postgrowth" economy about (Hardt et al., 2021) and how different economies or alternative economic models might leave growth behind (O'Neill et al., 2018; Hickel and Kallis, 2020). This attachment to growth is critical because it frames how climate change mitigation and negative emissions technologies are legitimized and communicated at the IPCC level. Within the IAM models there is a percentage of future GDP that must be allocated to each technology, the smaller the percentage the easier the political narrative (Livingston and Rummukainen, 2020). At the same time, however, that growth demands that we mine, extract, create, or consume our way to an economy $231 \%$ bigger than it is today, and during a moment when growth is extremely sluggish in OECD nations and previous drivers of growth-such as financial engineering, money creation, incorporation of women into the workforce and the privatization and marketization of previously public and common goods-is fast running low on new options (Hardt and Negri, 2009; Harvey, 2014).

Humanities and social sciences scholarship on GGR will have to contend with the notion that GGR options in capitalism are primarily evaluated relative to their deployment cost as a proportion of GDP. While GDP is a poor measure of human wellbeing, it is quite a good measure of how well-capitalism is doing because rising GDP means that, when one sector is exhausted, finance capital can switch capital into another sector. This is what Castree and Christophers (2015) have in mind when they explore options for liquid financial capital to find new, ecologicallypositive spatial fixes, including possibly negative emissions. The challenge for different GGR technologies may be less the actual ability to sequester carbon in a sustainable form, and more to be compatible with a monitoring, reporting, and evaluating function that is easily marketized, financed, and traded as a commodity.

The sections above have summarized a set of substantial debates that deserve greater attention by HASS scholars in the GGR debates. The tendencies of capitalism to crises, marketization, and the attendant necessity of long run GDP growth, all mean that HASS scholars of GGR deployment within capitalism have a challenging research agenda ahead, but one in which principle 1 has provided a useful starting point.

Principle 1: Greenhouse Gas Removal technologies are likely to emerge within capitalism, which is crisis prone, growth dependent, market expanding.

Before progressing further, we contend with the various expressions of capital across space and time to ground our analysis in actually-existing "capitalisms."

\section{VARIETIES OF CAPITALISM}

Given the various points in time and space where capitalism became established, it is no surprise that there are different expressions of capitalism in different geographic regions. While the generalities of principle 1 still hold, they do find multiple 
expressions. Our second principle therefore calls for GGR scholars in the social sciences to explore the different forms capitalism takes in a given space and time. Hall and Soskice (2001) "varieties of capitalism" contribution is key here. Their initial purpose was to explore how different institutional formations bred different social relations of capital accumulation and circulation across nations and regions. This included explorations of the different welfare state regimes (Mares, 2002), labor market policies (Wood, 2001), industrial strategies (Hancké, 2001), and Corporate Governance models (Vitolis, 2001) amongst others. In turn this led to broad characterizations of states into Liberal Market Economies (LMEs), exemplified by the Anglophone states where competition between firms, formal contracting, low unionization, and fluid labor and capital markets exist; and Coordinated Market Economies (CMEs), exemplified by Germany and comprising thicker corporate networks, patient, and stable capital relations between firms and finance, and a more formal relation with organized [skilled] labor (Schneider and Paunescu, 2012).

While the initial varieties of capitalism literature focussed on OECD nations, more recent work has expanded to include varieties of: Asian capitalism (Zhang and Whitley, 2013), postcommunist countries (Lane and Myant, 2007), and emerging economies (Schedelik et al., 2021). Accepting that capitalism comes in varieties is a foundational principle of comparative political economy (Hay, 2020). Much of the literature is concerned with the correct institutional mix to promote and sustain growth and economic performance. In this way the comparative political economy literature using the "varieties" approach is less critical, and is an example of our claim that HASS scholars can very well "say capitalism" without concluding, a la ŽiŽek, that its indefinite reproduction is impossible.

Climate change mitigation research using the "varieties of capitalism" school has explored: how different financial institutions across countries affect the deployment of renewable energy systems (Hall et al., 2016); how co-ordinated market economies can lead to a deeper lock-in of high carbon assets (Rentier et al., 2019); and how important institutional relations are in efforts to green the passenger car industry (Mikler, 2009). With recent examples beginning to explore how comparative political economy can be a powerful explanatory device for understanding which nations are likely to support carbon sink technologies and potentially negative emission technologies (Røttereng, 2018).

For HASS scholars looking to develop the debate around GGR in capitalism, the "varieties of capitalism" school, along with wider comparative political economy of climate mitigation, is a key body of work to synthesize. To proceed with such an endeavor principle 2 is necessary:

Principle 2: There are different varieties of capitalism and this will affect the feasibility of different GGR policies and supports in different nations.

By starting a journey using principles 1 and 2, we attend primarily to the material maintenance of capitalism, including state economic, labor, and financial policy, the construction of markets, and various economic diagnoses of poor or lagging performance. Markusson et al. (2018), however, also call us to attend to the ideational maintenance of capitalism. Whilst a more interpretive and less empirical endeavor, it is one that is nonetheless important to how HASS scholars bold enough to "say" capitalism can engage with GGR research. In the following section, we depart from drawing direct lines of enquiry to GGR research, for a time, to introduce the school of Critical Theory, which we find powerful for understanding the "public" challenge of GGR research.

\section{CAPITALISM AS IDEOLOGICALLY MAINTAINED}

"Critical Theory" is used as a shorthand to capture the critique of capitalism that was first developed by a group of German-Jewish scholars at the University of Frankfurt am Main in the 1930s, before their exile to the United States to escape the rising tide of fascism. If there is one principal idea that animates the work of the Frankfurt School theorists it is how capitalism as a total social system is able to suppress movements for genuine change by encouraging cultural, political, and economic freedoms, rather than through brute repression by state apparatus (Bottomore, 2002). It is through the idea that individuals are free-free to vote, free to shop, free to think-that capitalism is able to reproduce itself despite its crisis tendencies and the human/ecological damage it causes. The proponents of Critical Theory argue that the freedoms currently on offer are simply not capable of threatening the stability of the capitalist system and those who benefit from it.

In the 1930s, two prominent figures in Critical Theory-Max Horkheimer and Theodor Adorno-were trying to explain the crisis in Marx's theory of social change. In the period immediately after the First World War, there had been widespread social unrest in Europe. In particular, the 1917 Russian Revolution and the subsequent formation of the Soviet Union acted as a focal-point for left-wing Marxist ambitions and widespread hope that the capitalist system could be overthrown on the world stage (Kellner, 1990). As early as the mid-1920s, however, this dream was in rapid retreat. Intense battles were being fought inside left-wing socialist groups across Europe and, at the same time, powerful right-wing conservative responses were beginning to show that the possibility of a universal working class revolution-as Marx expected to happen-was becoming far less likely, especially in Germany. It was in this context that Adorno and Horkheimer founded their Institute for Social Theory at Frankfurt am Main, to protect the legacy of Marx's ideas from their apparent refutation by world events and, more generally, to prevent the wholesale elimination of left-wing ideas in Europe (Jay, 1996).

The Frankfurt School set about expanding Marx's ideas in a new direction, via Max Weber and Sigmund Freud, by shifting the focus away from political economy (material maintenance) and instead toward the themes of culture and ideology (ideational maintenance). Underpinning their approach was the hugely controversial claim that a Marxist social revolution could not 
happen precisely because the working class were now being incorporated into the capitalist system via what they called "Mass Culture" (Swingewood, 1977; Naremore, 1991). The working class were becoming a willing part of the capitalist system by embracing the "false freedoms" and "illusory individualism" handed out by the consumer market. More controversially still, Adorno and Horkheimer proposed that the working class, in becoming seduced by the consumer dreamworlds of Mass Culture, were increasingly responsible for the ability of capitalism to go on reproducing itself.

"Mass Society" thus refers to a large-scale, impersonal, and highly-rationalized set of social institutions. The idea is useful because it draws our attention to the ways in which daily life in complex modern societies, with their increasingly distant forms of power, can also become highly anonymous and appear not to care about or wish to support the important social relations that exist between the individual and their community. Mass Societies are rendered possible, so their argument goes, thanks to the technological advances of modern communications and electronic media. Culture in a Mass Society is therefore one that is transmitted to individuals for the purposes of consumption, rather than something that arises organically from the creative labors of daily life (Adorno and Horkheimer, 1944).

As fascism took hold in Germany, Adorno, and Horkheimer found refuge in the USA where rampant consumerism at that time dramatically shaped their thinking. The rise of the mass media, and specifically the leisure and entertainment industries, were understood in terms of their capacity to exploit this radical new category of individuals, namely the "consumer." Film, TV, and radio, were all seen as brutal evidence in the rise of what they called a "totally commodified culture," one in which everything was valued solely for its economic qualities (Adorno, 2001). As a result, individuals, especially when lacking the resources necessary to participate fully in a consumer culture, become further disempowered and lose a sense of their agency to drive forward meaningful change in their own lives and the wider world. As the sociologist Bauman (1999) has argued, there is an important distinction to be made between individuals de jure (those who are powerless over their own lives, but whom are nevertheless declared to be individuals by the social systems with which they interact) and individuals de facto (those who truly have influence to shape their own destiny and to make free choices).

The ability to promote individual freedoms through cultural choices without any real traction over the construction and maintenance of capitalist systems of production was seen by Adorno and Horkheimer as a new and highly-effective form of social control. Increasingly overworked, exploited, and alienated workers in the mass factories of the USA were not rebelling or forming into collective groups of unionized resistance in order to fight capitalism, which is what Marx had predicted. Instead, those workers were kept passive through the emergence of mass advertising and new media technologies, such that individuals were fast becoming passive consumers of mass-produced goods.

For Adorno and Horkheimer-and this is the second big idea in their whole argument-it was an "illusory sense of difference" created by advertisers and marketing professional that masked a more fundamental principle of similarity, namely the reproduction of capitalism, and the power of its ruling elite. The logic behind their complex argument is simple. The never-ending and rapid development of the capitalist economy in pursuit of greater profit creates more and more commodities that are then marketed to the consumer by evermore sophisticated new media technologies in such a way as to give the illusion of difference. In this way, market relations expand by manufacturing new "wants, needs, and desires" in order to stave-off material crises (Principle 1).

Adorno and Horkheimer argue that, whereas once "culture" had been a space for men and women to think and to act freely, it was now instead a sphere of almost total domination, one designed to complement and legitimize a crisis prone, growthaddicted, and commodifying mode of production (Principle 1). That is to say: with the emergence of advertising, "who we are" as individuals becomes synonymous with "what we buy." A sense of self is far less reliant on where we work, our values, and what roles we may have in our communities, and is rather communicated through the consumption and display of massproduced products.

According to Marx, capitalism is perpetually in a state of potential crisis (Principle 1) and to prevent those contradictions from reaching the point of actual crisis, capitalism produces ideology to construct reality in such a way that the underlying contradictions are not fully transparent. Ideology is rendered naturalistic or opaque through the deployment of culture as a system of cognitive repression enacted by ostensibly freely choosing consumers, but whose varied choices serve only to reinforce the system and stave off the crisis for another day. Through consumer goods and organized mass entertainment, ideology penetrates into the cultural sphere and ceases to be an illusion or a "false consciousness." One of the central arguments of the Frankfurt School was that the effectiveness of ideology as a system of control lies not so much in its false messages, but in its sheer ability to be able to remove the desire for change from society through its negation of critical thinking.

It is this idea, more recently expressed by Zygmunt Bauman as the "TINA syndrome" -i.e., "there is no alternative" - that has come to exemplify our current neoliberal stage of capitalist development. Across all of his work, from the early 1960s through to his last book Retrotopia (Bauman, 2017), Bauman invites us to see the world through the eyes of society's weakest members, and then to tell anyone honestly that capitalist societies are good, civilized, advanced, free. Today, such counter-cultural instincts seem as important as ever. Bauman became famous for his concept of "liquid modernity" (Bauman, 2013), a sense that once reliable forms of labor or obdurate social institutions were no longer solid or fixed.

There is a key resonance here with Principle 2, since the different varieties of capitalism literatures are concerned with re-ordering state involvement in the economy, labor, and financial relations. In order to ensure economic performance, old institutions and relations are "melted away" in order to produce comparative advantage, with little thought to the social damage such uncertainty causes for the communities it affects. Similarly, Bauman's notion of the liquidity of modern life resonates with 
Castree and Christophers' (2015) description of finance capital's ability to "melt present solidities into air."

Bauman attends to the human and cultural consequences of such rapid and consistent re-ordering of social institutions, where individuals are shorn of reliable life strategies and the institutions or social relations that surround them. The individual de jure becomes a precarious state, where once relevant and valuable skills are rendered obsolete and there is no guarantee that the acquisition of new skills, life strategies, or social institutions/relations will be successful, endure, or reproduce the freedom to consume for very long.

In parallel, real power becomes remote and inaccessible. Recall from principle 1 the effect of infrastructure financialization, where local autonomy is subordinated to the needs of finance capital (O'Neill, 2019). The cultural effects of this "liquid society" and removal of de facto individual agency render public concerns moot and futile to engage with. Bauman notes a retreat from the agora, from public decision-making over collective futures, fuelled by a sense that these public decisions are nolonger meaningful, and that distant others are preventing any real change.

A key feature of Bauman's analysis of "liquid modernity", as Davis M. (2020) has argued, is an apparent divorce of power from politics, leading to the leaking away of trust from political leaders on all sides. The divorce of power from politics-such a repeated argument in the latter part of Bauman's career, understood as the emancipation of capital from the territorially-fixed controls of states-means that national politicians are no longer able to fulfill their traditional functions amidst the stupefying pace of (technologically-enabled) change. This political impotence creates a new legitimation crisis (Habermas, 1988), which sees that same modern impulse to perfect society directed toward the only "imagined community" (Anderson, 2006) left available to it- "the past." If the future is only to be feared, because we have become so removed from the idea of genuine societal transformation and the possibility of "life after capitalism," then let us only face backwards and revel in a nostalgic recreation by daring to utilize various degrees of palingenesis to see the nation "reborn," to "take back control," to become "great again." This is how what Bauman (2017) called the retrotopic imaginary seeks safety, in the comfort of perceived certainties long since gone.

The ramifications of a Mass Culture of consuming individuals, with a very precarious and uncertain sense of themselves, fuelled by a suspicion that real power is far away from them, is of critical importance to greenhouse gas removal scholars. The work of Cox, outlined above, demonstrated there is a clear suspicion that GGR technologies do nothing other than justify a "non-transition" and, under the surface of these stated concerns of "mitigation delay" and other rational responses, resides a recognition that what currently "is" is not very satisfying. However, inchoate that sentiment may be, it is worth further research to excavate, and in particular should be linked to popular but similarly inchoate calls to "build back better" from the Covid-19 pandemic, a slogan striking a similar note to those mentioned above given its retrotopic chord. Conversely, calls for a "Green New Deal" exist because a new deal is needed, since what we have now is quite simply "not fair" (Hampden-Turner and Trompenaars, 2021).

Leveraging and exploring where GGR fits in these "mass culture" narratives is a productive avenue of research and links back to ways in which different publics and constituencies are formed around GGR issues (Bellamy and Healey, 2018). Adopting a Critical Theory register arms us with a controversial, and somewhat "darker" notion (Pollock and Davis, 2020), that some publics are operating with a sense of precarity and uncertainty, completely at odds with the "mass culture" around them and likely to comprise a rather messy and angry ideological soup that is a direct product of the realities of "market force" meeting the unreality of mass culture (Hopkin, 2017; Davis A. E., 2020; Davis M., 2020). Making space for this confusion, anger, and sense of precarity that is produced by the ideational maintenance of capitalism will be important.

Consider the following from the perspective of different "publics" in the Humber region: what "we" are asking for, if we want to treat proposals like "Zero Carbon Humber" seriously, is the creation of a fictitious market for an invisible gas to be taken from the air, and then for that invisible gas to be sent through invisible pipes, subsidized by public money, into invisible caverns, to mitigate a problem which will become apparent in decades. "We" are proposing this in a region of long-term economic stress where immediate need is apparent in schools and public services that are suffering from multiple years of austerity and slow growth. "We" are doing so in a cultural climate of precarity, uncertainty, and extreme mistrust in the possibility of a stable future (Bauman, 2013). For these reasons, we argue it is important to pay far closer attention to the ideological maintenance of capitalism and the cultural mileux we as social scientists are entering when we try to think through problems of social legitimacy and consent. As such, we ask HASS GGR scholars to proceed with principle 3 .

Principle 3: Capitalism is more than an economic system, it is ideologically and culturally maintained.

\section{CONCLUSION}

This article has explored the ways in which HASS scholars coming to the field of greenhouse gas removal can do so in ways which recognize and contend with capitalism. We began with establishing a dividing line between contributions which name and contend with "capitalism" explicitly and those which gesture toward an unnamed "global economy." We then set out the difficult space one is invited to inhabit when capitalism is named, which begins a journey toward ŽiŽeks "ultimatum" to either endorse capitalism's naturalization by endeavoring to make it more just, or conclude that its contradictions and tensions are too great for it to be sustained. We do not invite HASS GGR researchers to declare their conclusions just yet; instead, we present three guiding principles that we think could be used to shape the social science of greenhouse gas removal. Principles that go beyond "instrumental" service to techno economic modeling and invite a more critical position. 
The first principle recognizes GGR technologies will emerge within capitalism. Even if state delivered, they will be delivered by a capitalist state, and capitalism, wherever it is found is crisis prone, growth dependent and market expanding. There are several productive avenues of research available to those focusing on Principle 1, not least the ways in which GGR projects and deployment can be approached as a spatio-temporal or socioecological "fix" to the crisis tendencies of capital, and how a GGR economy might arise in a non-capitalist "growth agnostic" political economy.

The second principle recognizes that capitalism finds different expressions in place and time and while Principle 1 holds, its individual expressions will be necessarily diverse. GGR policy that will work in Germany will not work in Brazil, or at least not in the same ways. This is due to different institutional structures and balances of state involvement in the economy, financial institutions, and labor bargaining power to name just a few. Recognizing the "Varieties of Capitalism" literature is broadly oriented toward improving national economic performance should also strengthen our claim that HASS scholars "saying" capitalism, need not be in the process of rejecting it.

Finally, principle 3 draws our attention to the ways in which critical social theory can be used to explore how capitalism is not only maintained through material political means but also has an ideational and ideological dimension that is transmitted through mass culture, and that breaking down old institutional certainties

\section{REFERENCES}

Adorno, T. (2001). The Culture Industry: Selected Writings on Mass Culture, 2nd $E d n$. London: Routledge Classics.

Adorno, T., and Horkheimer, M. (1944). Dialectic of Enlightenment. New York: Continuum.

Anderson, B. (2006). Imagined Communities: Reflections on the Origin and Spread of Nationalism. London: Verso.

Apostolopoulou, E. (2021). Tracing the links between infrastructureled development, urban transformation, and inequality in China's belt and road initiative. Antipode 53, 831-858. doi: 10.1111/ant i. 12699

Barbier, E. B., and Burgess, J. C. (2017). Natural resource economics, planetary boundaries and strong sustainability. Sustainability 9:1858. doi: 10.3390/su9101858

Bauman, Z. (1999). Culture as Praxis. London; New York, Thousand Oaks, CA: Sage.

Bauman, Z. (2013). Liquid Modernity. Cambridge: Polity Press.

Bauman, Z. (2017). Retrotopia. Cambridge: Polity Press. doi: 10.14515/monitoring.2018.6.22

Bellamy, R., and Healey, P. (2018). 'Slippery slope' or 'uphill struggle'? Broadening out expert scenarios of climate engineering research and development. Environ. Sci. Policy 83, 1-10. doi: 10.1016/j.envsci.2018. 01.021

Böhm, S., Misoczky, M. C., and Moog, S. (2012). Greening capitalism? A Marxist critique of carbon markets. Organ. Stud. 33, 1617-1638. doi: $10.1177 / 0170840612463326$

Bonizzi, B., and Powell, J. (2020). "What causes economic crises? And what can we do about them?" in Recharting the History of Economic Thought, Red Globe Press, eds K. Deane and E. Van Waeyenberge (London: Red Globe Press), 167-182.

Bottomore, T. (2002). The Frankfurt School and Its Critics. London: Routledge. doi: $10.4324 / 9780203407110$ produces real tensions and precarity which will be operating in any sphere of public discourse. These tensions are unlikely to be explicit and will need deeper interpretation and analysis than instrumental and empirical social science is able to provide.

Our hope is that this contribution will spark debate on greenhouse gas removal in capitalism and lead to a set of critical reflections at the very early stages of GGR development and deployment. We expect a healthy debate on the suitability of the three principles proposed and welcome any attempt to operationalize them in future GGR research.

\section{DATA AVAILABILITY STATEMENT}

The original contributions presented in the study are included in the article/supplementary material, further inquiries can be directed to the corresponding author/s.

\section{AUTHOR CONTRIBUTIONS}

SH and MD developed the manuscript, principles, and concepts of the article in tandem. Both authors contributed to the article and approved the submitted version.

\section{FUNDING}

Funds received for open access publication by institution.
Bourayou, C., and Van Waeyenberge, E. (2020). "How do economies grow," in Recharting the History of Economic Thought, eds K. Deane and E. Van Waeyenberge (London: Red Globe Press), 183-208.

Bowman, A., Ertürk, I., Froud, J., Johal, S., and Law, J. (2014). The End of the Experiment?: From Competition to the Foundational Economy. Manchester: Manchester University Press. doi: 10.7765/9781847798930

Büchs, M., and Koch, M. (2017). Postgrowth and Wellbeing: Challenges to Sustainable Welfare. Cham: Springer. doi: 10.1007/978-3-319-59903-8

Carton, W. (2019). "Fixing" climate change by mortgaging the future: negative emissions, spatiotemporal fixes, and the political economy of delay. Antipode 51, 750-769. doi: 10.1111/anti.12532

Castree, N., Adams, W. M., Barry, J., Brockington, D., Büscher, B., Corbera, E., et al. (2014). Changing the intellectual climate. Nat. Clim. Chang. 4, 763-768. doi: $10.1038 /$ nclimate2339

Castree, N., and Christophers, B. (2015). Banking spatially on the future: capital switching, infrastructure, and the ecological fix. Ann. Assoc. Amer. Geograph. 105, 378-386. doi: 10.1080/00045608.2014.985622

Cox, E., Spence, E., and Pidgeon, N. (2020a). Public perceptions of carbon dioxide removal in the United States and the United Kingdom. Nat. Clim. Chang. 10, 744-749. doi: 10.1038/s41558-020-0823-z

Cox, E., Spence, E., and Pidgeon, N. (2020b). Incumbency, trust and the Monsanto effect: stakeholder discourses on greenhouse gas removal. Environ. Values 29,197-220. doi: 10.3197/096327119X15678473650947

Davis, A. E. (2020). Waves of populism: a recent manifestation of Polanyi’s "double movement?" J. Econ. 54, 398-403. doi: 10.1080/00213624.2020.1743602

Davis, M. (2020). Hermeneutics contra fundamentalism: Zygmunt Bauman's method for thinking in dark times. Thesis Eleven 156, 27-44. doi: $10.1177 / 0725513619898285$

Dowd, A.-M., Rodriguez, M., and Jeanneret, T. (2015). Social science insights for the BioCCS industry. Energies 8, 4024-4042. doi: 10.3390/en8054024

Earle, J., Moran, C., and Ward-Perkins, Z. (2016). The Econocracy: The Perils of Leaving Economics to the Experts. Manchester: Manchester University Press. doi: 10.7228/manchester/9781526110121.001.0001 
Ekers, M., and Prudham, S. (2018). The socioecological fix: fixed capital, metabolism, and hegemony. Ann. Assoc. Amer. Geograph. 108,17-34 doi: 10.1080/24694452.2017.1309963

Forster, J., Vaughan, N. E., Gough, C., Lorenzoni, I., and Chilvers, J. (2020). Mapping feasibilities of greenhouse gas removal: key issues, gaps and opening up assessments. Glob. Environ. Change 63:102073. doi: 10.1016/j.gloenvcha.2020.102073

Giacché, V. (2011). Marx, the falling rate of profit, financialization, and the current crisis. Int. J. Polit. Econ. 40, 18-32. doi: 10.2753/IJP0891-1916400302

Groom, B., and Talevi, M. (2020). "How does economics address the environment," in eds K. Deane and E. Van Waeyenberge, Recharting the History of Economic Thought (London: Macmillan), 247-268.

Habermas, J. (1988). Legitimation Crisis. Trans. by T. McCarthy. Cambridge: Polity Press.

Hall, P. A., and Soskice, D. (ed.). (2001). Varieties of Capitalism. The Institutional Foundations of Comparative Advantage. Oxford: Oxford University Press.

Hall, S., Foxon, T. J., and Bolton, R. (2016). Financing the civic energy sector: how financial institutions affect ownership models in Germany and the United Kingdom. Energy Res. Soc. Sci. 12, 5-15. doi: 10.1016/j.erss.2015.11.004

Hampden-Turner, C., and Trompenaars, F. (2021). Culture, Crisis and COVID-19: The Great Reset. Cambridge: Cambridge Scholars Publishing.

Hancké, B. (2001). "Revisiting the french model: coordination and restructuring in french industry," in Varieties of Capitalism. The Institutional Foundations of Comparative Advantage, eds P. A. Hall and D. Soskice (Oxford: Oxford University Press), 307-334. doi: 10.1093/0199247757.003.0009

Hardt, L., Barrett, J., Taylor, P. G., and Foxon, T. J. (2021). What structural change is needed for a post-growth economy: a framework of analysis and empirical evidence. Ecol. Econ. 179:106845. doi: 10.1016/j.ecolecon.2020.106845

Hardt, M., and Negri, A. (2009). Commonwealth. Cambridge, MA: Harvard University Press. doi: $10.2307 /$ j.ctvjsf $48 \mathrm{~h}$

Harvey, D. (1978). The urban process under capitalism: a framework for analysis. Int. J. Urban Reg. Res. 2:101-131. doi: 10.1111/j.1468-2427.1978.tb00738.x

Harvey, D. (2010). The Enigma of Capital and the Crises of Capitalism. London: Profile Books.

Harvey, D. (2014). Seventeen Contradictions and the End of Capitalism. London: Profile Books.

Harvey, D. (2017). Marx, Capital, and the Madness of Economic Reason. Oxford University Press.

Hay, C. (2020). Does capitalism (still) come in varieties? Rev. Int. Polit. Econ. 27, 302-319. doi: 10.1080/09692290.2019.1633382

Hickel, J., and Kallis, G. (2020). Is green growth possible? New Polit. Econ. 25, 469-486. doi: 10.1080/13563467.2019.1598964

Hopkin, J. (2017). When Polanyi met Farage: market fundamentalism, economic nationalism, and Britain's exit from the European Union. Brit. J. Polit. Int. Relat. 19, 465-478. doi: 10.1177/1369148117710894

IIASA (2020). IAMC 1.5c Scenario Explorer hosted by IIASA. Available online at: https://data.ene.iiasa.ac.at/iamc-1.5c-explorer/\#/workspaces (accessed May 2021).

Jackson, T. (2009). Prosperity Without Growth: Economics for a Finite Planet. London: Routledge. doi: 10.4324/9781849774338

Jackson, T. (2021). Post-Growth: Life After Capitalism. Cambridge: Polity.

Jacobs, M., and Mazzucato, M. (eds.). (2016). Rethinking Capitalism: Economics and Policy for Sustainable and Inclusive Growth. Chichester: John Wiley and Sons.

Jay, M. (1996). The Dialectical Imagination: A History of the Frankfurt School and the Institute of Social Research, 1923-1950. Vol. 10. Berkeley, CA: Univ of California Press.

Jessop, B. (2006). "Spatial fixes, temporal fixes and spatio- temporal fixes," in David Harvey: A Critical Reader, eds N. Castree and D. Gregory (Chichester: John Wiley and Sons), 142-166. doi: 10.1002/9780470773581.ch8

Jessop, B., and Sum, N. L. (2006). Beyond the Regulation Approach: Putting Capitalist Economies in Their Place. Glos: Edward Elgar Publishing.

Kellner, D. (1990). Critical theory and the crisis of social theory. Sociol. Perspect. 33, 11-33. doi: $10.2307 / 1388975$

Knox-Hayes, J. (2013). The spatial and temporal dynamics of value in financialization: analysis of the infrastructure of carbon markets. Geoforum 50, 117-128. doi: 10.1016/j.geoforum.2013.08.012
Lamb, W. F., Antal, M., Bohnenberger, K., Brand-Correa, L. I., Müller-Hansen, F., Jakob, M., et al. (2020). What are the social outcomes of climate policies? A systematic map and review of the ex-post literature. Environ. Res. Lett. 15:113006. doi: 10.1088/1748-9326/abc11f

Lane, D., and Myant, M. R. (eds.). (2007). Varieties of Capitalism in Post-Communist Countries. Basingstoke: Palgrave Macmillan, p. xiv. doi: $10.1057 / 9780230627574$

Lenzi, D., Lamb, W. F., Hilaire, J., Kowarsch, M., and Minx, J. C. (2018). Don't deploy negative emissions technologies without ethical analysis. Nature 561, 303-305. doi: 10.1038/d41586-018-06695-5

Livingston, J. E., and Rummukainen, M. (2020). Taking science by surprise: the knowledge politics of the IPCC special report on 1.5 degrees. Environ. Sci. Policy 112, 10-16. doi: $10.1016 / j$.envsci.2020.05.020

Mares, I. (2002). "Firms and the welfare state: when, why, and how does social policy matter to employers?", in Varieties of Capitalism. The Institutional Foundations of Comparative Advantage, eds P. A. Hall and D. Soskice (Oxford: Oxford University Press), 184-212. doi: 10.1093/0199247757.003.0005

Markusson, N., Balta-Ozkan, N., Chilvers, J., Healey, P., Reiner, D., and McLaren, D. (2020). Social science sequestered. Front. Clim. 2:2. doi: 10.3389/fclim.2020.00002

Markusson, N., Gjefsen, M. D., Stephens, J. C., and Tyfield, D. (2017). The political economy of technical fixes: the (mis) alignment of clean fossil and political regimes. Energy Res. Soc. Sci. 23, 1-10. doi: 10.1016/j.erss.2016.11.004

Markusson, N., McLaren, D., and Tyfield, D. (2018). Towards a cultural political economy of mitigation deterrence by negative emissions technologies (NETs). Glob. Sustain. 1:e10. doi: 10.1017/sus.2018.10

Mikler, J. (2009). Greening the Car Industry: Varieties of Capitalism and Climate Change. Cheltenham: Edward Elgar Publishing. doi: 10.4337/9781849802246

Naremore, J. and Brantlinger, P. (eds.). (1991). Modernity and Mass Culture. Bloomington: Indiana University Press.

O'Neill, D. W., Fanning, A. L., Lamb, W. F., and Steinberger, J. K. (2018). A good life for all within planetary boundaries. Nat. Sustain. 1, 88-95. doi: 10.1038/s41893-018-0021-4

O'Neill, P. (2019). The financialisation of urban infrastructure: a framework of analysis. Urb. Stud. 56, 1304-1325. doi: 10.1177/0042098017751983

Polanyi, K., and MacIver, R. M. (1944). The Great Transformation, Vol. 2. Boston, MA: Beacon Press. p. 145.

Pollock, G., and Davis, M. (2020). Thinking in dark times: assessing the transdisciplinary legacies of Zygmunt Bauman. Thesis Eleven 156, 3-9. doi: 10.1177/0725513619898090

Raworth, K. (2017). Doughnut Economics: Seven Ways to Think Like a 21st-Century Economist. Chelsea Green Publishing.

Rentier, G., Lelieveldt, H., and Kramer, G. J. (2019). Varieties of coalfired power phase-out across Europe. Energy Policy 132, 620-632. doi: 10.1016/j.enpol.2019.05.042

Rogelj, J., Popp, A., Calvin, K. V., Luderer, G., Emmerling, J., Gernaat, D., et al. (2018). Scenarios towards limiting global mean temperature increase below 1.5०C. Nature Clim. Change 8, 325-332. doi: 10.1038/s41558-018-0091-3

Rose, D. B., Van Dooren, T., Chrulew, M., Cooke, S., Kearnes, M., and O'Gorman, E. (2012). Thinking through the environment, unsettling the humanities. Environ. Human. 1, 1-5. doi: 10.1215/22011919-3609940

Røttereng, J. K. S. (2018). The comparative politics of climate change mitigation measures: who promotes carbon sinks and why? Glob. Environ. Polit. 18, 52-75. doi: 10.1162/GLEP_a_00444

Sapinski, J. P., Buck, H. J. and Malm, A. eds., (2020). Has It Come to This?: The Promises and Perils of Geoengineering on the Brink. New Brunswick, NJ: Rutgers University Press. doi: 10.36019/9781978809390

Schedelik, M., Nölke, A., Mertens, D., and May, C. (2021). Comparative capitalism, growth models and emerging markets: the development of the field. New Polit. Econ. 26, 514-526. doi: 10.1080/13563467.2020.1807487

Schneider, M. R., and Paunescu, M. (2012). Changing varieties of capitalism and revealed comparative advantages from 1990 to 2005: a test of the Hall and Soskice claims. Socio Econ. Rev. 10, 731-753. doi: 10.1093/ser/mwr038

Schumpeter, J. A. (1934). The theory of economic development. Transl. by R. Opie. Harv. Econ. Stud. 46, 1600-0404.

Shaikh, A. (2016). Capitalism: Competition, Conflict, Crises. Oxford: Oxford University Press. doi: 10.1093/acprof:oso/9780199390632.001.0001 
Stern, N. (2006). Stern Review: The Economics of Climate Change. Cambridge: Cambridge University Press. doi: 10.1017/CBO9780511817434

Sweezy, P. (1942). The Theory of Capitalist Development. New York: Monthly Review Press.

Swingewood, A. (1977). The Myth of Mass Culture. London: Palgrave. doi: $10.1007 / 978-1-349-15783-9$

Torrance, M. (2009). The rise of a global infrastructure markets through relational investing. Econ. Geogr. 85, 75-97. doi: 10.1111/j.1944-8287.2008.0 1004.x

Vitolis, S. (2001). "Varieties of corporate givfernance: comparing Germany and the UK," in Varieties of Capitalism. The Institutional Foundations of Comparative Advantage, eds P. A. Hall and D. Soskice (Oxford: Oxford University Press), 337-360.

Waller, L., Rayner, T., Chilvers, J., Gough, C. A., Lorenzoni, I., Jordan, A., et al. (2020). Contested framings of greenhouse gas removal and its feasibility: social and political dimensions. Wiley Interdiscipl. Rev. Clim. Change 11:e649. doi: $10.1002 /$ wcc. 649

Wiedenhofer, D., Virág, D., Kalt, G., Plank, B., Streeck, J., Pichler, M., et al. (2020). A systematic review of the evidence on decoupling of GDP, resource use and GHG emissions, part I: bibliometric and conceptual mapping. Environ. Res. Lett. 15:063002. doi: 10.1088/1748-9326/ab8429

Wood, E. M. (2002). The Origin of Capitalism: A Longer View. Brooklyn, NY: Verso Books.

Wood, S. (2001). "Business, government, and patterns of labor market policy in Britain and the Federal Republic of Germany," in Varieties of Capitalism. The Institutional Foundations of Comparative Advantage, eds
P. A. Hall and D. Soskice (Oxford: Oxford University Press). 247-274, doi: 10.1093/0199247757.003.0007

Zhang, X., and Whitley, R. (2013). Changing macro-structural varieties of East Asian capitalism. Socio Econ. Rev. 11, 301-336. doi: 10.1093/ser/mws029

Žižek, S. (2008) SubStance. The Political Animal, Vol. 37. Baltimore, MD: The Johns Hopkins University Press. 37-72. doi: 10.1353/sub.0.0017

Žižek, S. (2017). The Courage of Hopelessness: Chronicles of a Year of Acting Dangerously. New York, NY: Penguin UK.

Conflict of Interest: The authors declare that the research was conducted in the absence of any commercial or financial relationships that could be construed as a potential conflict of interest.

Publisher's Note: All claims expressed in this article are solely those of the authors and do not necessarily represent those of their affiliated organizations, or those of the publisher, the editors and the reviewers. Any product that may be evaluated in this article, or claim that may be made by its manufacturer, is not guaranteed or endorsed by the publisher.

Copyright (c) 2021 Hall and Davis. This is an open-access article distributed under the terms of the Creative Commons Attribution License (CC BY). The use, distribution or reproduction in other forums is permitted, provided the original author(s) and the copyright owner(s) are credited and that the original publication in this journal is cited, in accordance with accepted academic practice. No use, distribution or reproduction is permitted which does not comply with these terms. 